\title{
Open Education Co-Design as a Participatory Pedagogy in an Online Graduate Program
}

\author{
Barbara Brown \\ Werklund School of Education \\ University of Calgary \\ Christie Hurrell \\ Libraries and Cultural Resources \\ University of Calgary \\ Verena Roberts \\ Werklund School of Education \\ University of Calgary \\ Michele Jacobsen \\ Werklund School of Education \\ University of Calgary \\ Nicole Neutzling \\ Werklund School of Education \\ University of Calgary \\ Mia Travers-Hayward \\ Department of Sociology \\ London School of Economics \\ Correspondence: Barbara Brown \\ University of Calgary, Calgary AB, Canada \\ Email: babrown [at] ucalgary.ca
}

\begin{abstract}
This paper builds on student-instructor partnerships by describing how an instructor, students, program coordinator, and members of a research team were involved in the co-design of an open educational resource in a graduate program in education. A four-part open learning design framework was used to guide the course design: (a) clarifying the co-design process; (b) building and sharing knowledge, and making thinking visible; (c) building relationships; and (d) sustaining learning beyond the course. The framework, along with the collaborative team effort that was part of a larger research project, enabled the development of an openly licensed and accessible digital book. The project brought together a collaborative team who were passionate about learning more about open education and a small grant supported the additional expense of professional copyediting to refine the book.
\end{abstract}

Keywords: co-design, open educational practice, open educational resource, higher education, online learning 


\section{Co-design \& Participatory Pedagogy}

In design research there has been a notable shift from a user-centred approach to a more participatory and co-designed approach where the user is considered a partner and involved in all phases of a generative development (Barbera et al., 2017; Sanders \& Stappers, 2008). In a user-centred approach, the user might be invited part way through a project, for example, to conduct usability testing, whereas when using a co-designed approach, the user is a partner and involved in all phases of development (Sanders \& Stappers, 2008). Co-design relocates the user from consumer to producer and in educational contexts this situates students as knowledge creators in the learning activities instead of recipients of knowledge (De Rosa \& Robinson, 2017; Jahnke et al., 2020). Students who are part of the co-design process within an interactive learning environment have a personal investment in the learning task, which can be described as participatory pedagogy used in the classroom (DiPietro, 2013; Sanders \& Stappers, 2008). In other words, co-design can be a methodology implemented by instructors along with their students (Barbera et al., 2017). Co-design can also be considered a highly facilitated instructional process that can lead to the development of educational innovations (Roschelle et al., 2006). Consistent with Gee's (2005) principle of learning in video gameplay, co-design can be simply described as a way to empower learners as active agents in a highly student-centred learning experience (De Rosa \& Robinson, 2017; Wiley \& Hilton, 2018).

User participation and interaction in design processes is an important aspect of co-design (Sarmiento-Pelayo, 2015). For example, in an edited volume, graduate student authors, with assistance from undergraduate student editors, described a range of student-centered learning and teaching practices and described their book as "both a product of student-centered learning and part of that process" (Ashton, 2017, p. 13). Students can be empowered learners through participatory pedagogy and by co-designing open educational content, connecting with scholarly communities, and working in public spaces (DeRosa \& Robinson, 2017). Co-design can provide an opportunity for students to take learning beyond the expectations of the instructor or intentions of a course design and extend the value of their work beyond the course (Jahnke et al., 2020; Paskevicius \& Irvine, 2019).

Research on co-design in digital and open learning environments highlights the importance of describing a situated context when examining learning processes and the roles of instructors and students in the learning process (Barbera et al., 2017; Clinton-Lisell, 2021). Rich descriptions of pedagogical designs in open education contexts can contribute to a deepened understanding of openness in teaching and learning (Paskevicius \& Irvine, 2019). The focus of this paper is to describe the learning design framework that guided how graduate students worked together with their instructor, peers, and members of a research team to co-design chapters for an open pressbook, an openly licensed digital book that can be easily accessed, reused, revised, and remixed, within a graduate program in educational technology. The research team was comprised of experts in educational technology, including the course instructor, program coordinator, and another faculty member, as well as a librarian, and a master's level graduate and undergraduate research assistant. The team received modest financial support from a Scholarship of Teaching and Learning-focused grant, which funded the two research assistants as well as a professional copyeditor. Additionally, the team took advantage of an institutionally supported Pressbooks instance to host and distribute the final open educational resource (OER). 


\section{Open Learning Design Framework}

This section describes the open learning design framework that was used to guide the course design (Roberts, 2019). Students prepared a draft chapter for an OER in the Ethics and Technology class, which is part of the Leading the Learning in a Digital Age four-course online Master's certificate offered in the Werklund School of Education, University of Calgary. The two courses that precede the Ethics and Technology course, Interdisciplinary Learning and Technology and Technological Literacy, provided a foundation for writing the chapter while a subsequent course, Leading Citizenry in a Digital Age, helped students consider knowledge mobilization. Collaboration with members of the research team and working with a professional copyeditor also helped students complete their final chapters for publication, which occurred after completion of the four courses in the program.

The four interconnected parts of the open learning design framework included: (a) clarifying the co-design process and negotiating each learners' personal learning pathway; (b) building and sharing knowledge through learners choosing how to communicate their learning and make thinking visible; (c) building learning relationships; and, (d) sustaining the learning beyond the course, and throughout the writing process, by developing and expanding upon personal learning networks (Roberts, 2019). We expanded on this framework by extending learning relationships to include members of the research team.

\section{Clarifying the Co-Design Process}

The activities leading towards the development of a chapter were designed as a layered and supportive pathway to provide students with multiple opportunities to share their ideas and to receive ongoing and continual feedback. Students selected a topic of their choice based on their earlier course work, the readings provided during the program, and personal interests in technological and ethical issues. Topic selection was bounded using Farrow's (2016) Framework of Ethics for Open Education and required students to select a topic relating to the safe and ethical use of technology in digital learning environments. Students conducted further literature searches to support their topic of inquiry and prepared an outline and one-minute pitch as part of their course work. The course outline described co-design as follows:

Learning is a shared responsibility. As such, in this course, the students will explore the ways in which students and instructors can share the process of co-designing learning within one graduate course. The students and instructor will co-design and develop an open educational resource (OER), in this case a pressbook, as a framework for codesigning participatory pedagogy and conditions for learning. Pressbooks is a sustainable and openly shared digital publishing tool to create an openly licensed digital textbook that current and future students can reuse, revise and remix with others. The pressbook is being created and hosted in conjunction with the Taylor Family Digital Library as a pilot for other University of Calgary courses.

\section{Building and Sharing Knowledge \& Making Thinking Visible}

The students were expected to work alongside and with other students to regularly offer feedback when peers shared their outlines and pitched their ideas. When searching for literature, the students would often find relevant literature for their peers. Students were encouraged as co-designers and active participants to share resources with peers and help peers throughout the learning process. Students were organized into self-selected social pods 
to connect, interact, and give feedback to each other throughout the course (DeWaard \& Roberts, 2021). The social pods were intended to provide an opportunity for the students to clarify course expectations and develop trusting relationships with peers throughout the course.

Chapter development involved several stages. First, students developed an initial draft chapter and engaged in iterative cycles of formative feedback with peers and their instructor. Then, students engaged with experts external to the course to receive additional feedback on their draft chapters (students were provided assistance with identifying external experts if necessary). Students used a variety of tools and techniques for engaging with each other and to give and receive feedback, either synchronously during class time (e.g., Zoom chats) or pre-recorded and asynchronously, using collaborative authoring tools (e.g., Google docs), discussion threads, or informally through social media conversations using the class hashtag \#EdTechEthics. Specific feedback activities were designed within the course (e.g., one-minute pitch); however, other feedback activities developed more serendipitously as the students discovered how and with whom they needed to connect and interact. The choice and variety of feedback activities highlights the need to consider students' diverse levels of readiness to engage in open educational practices (Cronin, 2017). The following information was included in the course outline to help prepare students for this formative feedback, which was described as "feedback loops":

The role of the instructor is to facilitate the work and to support students as they engage in the learning tasks. The course is designed to ensure the students connect and interact with multiple feedback loops throughout the course. The feedback loops include group feedback, outside of the class feedback and instructor feedback. The instructor will also provide students with ongoing, timely, and constructive feedback to further their learning and growth in interdisciplinary learning and technology.

Students were asked to reflect upon their open learning experiences in a final reflective assignment as a way to help make their thinking and learning visible to themselves, their instructor, and others. Students reflected on the learning process and the sequence of the layered learning tasks and formative feedback. Students were open to active learning and collaboration with peers and others. According to the students, formative assessment and reflection emerged as key approaches that were part of the co-design process and layered assignments that supported their engagement in learning. At the end of the course, each student submitted their draft chapter and personal reflection to fulfill course requirements. An option for all students in the program was the opportunity to contribute their chapters for inclusion in the OER pressbook. For example, in the 2019 cohort, nine students contributed to the pressbook out of 12 students enrolled in the program (Brown et al., 2020).

\section{Building Learning Relationships}

Throughout the Ethics in Technology course, students were building relationships (e.g., peer relations, instructor-peer relations, relations with content experts). Peer groups were often mentioned by students as an important support as they navigated a challenging assignment. Following the course, students also started to develop relationships with members of the research team when they were refining and finalizing their chapters. During this period, students were also invited to complete a survey, participate in a semi-structured interview, and share artifacts from their learning experiences in the program. As reported in Jacobsen et al. (2021), results suggested that developing human interactions and building relationships through a co- 
design model which integrates digital tools enabled the development of OER and provided an authentic scholarly activity that engaged students in collaborative knowledge building.

The open learning design framework (Roberts, 2019) used in the Ethics and Technology course helped students actively engage in the co-design process as a participatory pedagogy while developing an OER (Jacobsen et al., 2021). In this learning design, we also noted the value of developing extended relationships and interactions beyond the course that supports the development of a learning community through a connection of personal learning networks. Relationships with outside content experts and members of the research team, including the program coordinator, librarian, and research assistants, contributed to the co-design and completion of the chapters in the Pressbook, and extended beyond the duration of the course and the program.

\section{Sustaining Learning Beyond the Course}

Students approached outside experts during the course work for different types of feedback and assistance as they were developing their chapters (e.g., conceptualizing ideas, recommendations for literature, reviewing drafts). Although it was uncomfortable for some students to ask family members, let alone reach out to experts outside of the classroom, the students reported they appreciated how this collaboration could help develop their personal learning networks and forge connections that could be carried beyond the duration of the graduate program. Experts from outside the class (e.g., academic librarians, many of the authors of the assigned course readings, program coordinator) were integrated into the course design intentionally through webinars and added as suggested expert support in weekly instructor emails and in communications using the course hashtag. The program coordinator role for the Master's certificate is a voluntary service-role, and after the course was completed, the coordinator helped facilitate the process for further feedback and refinement of the chapters. The draft chapters were reviewed by two members of the research team for content, and two other members of the team for format, including APA citations and references. Following these reviews, the chapters were returned to students to consider and implement changes. After students completed their final edits and changes, the librarian on the research team prepared the Pressbook and worked with the team to help upload the final versions of the chapters. A professional copy editor, who was funded through the research grant, reviewed the final chapters and suggested final changes. Students were provided with one more opportunity to finalize their chapters prior to publication. The total process for completing the OER, including the 12-week Ethics and Technology course, and the back-and-forth communications with the chapter authors and edits, took one year. Project momentum was sustained through a combination of grant funding, enthusiasm and commitment from the students and the team, including the course instructor and program coordinator, and the diverse range of expertise that the research team brought to this project.

\section{Conclusion}

The four parts of the open learning design framework were used to describe the co-design that occurred in this project: (a) clarifying co-design processes and individual learners' pathways; (b) building and sharing knowledge through learners' choice for communication and making thinking visible; (c) building learning relationships; and, (d) sustaining learning beyond the course and expanding personal learning networks (Roberts, 2019), including relationships with members of the research team. Infrastructure support, such as institutional access to Pressbooks content management system and research grant funding, helped make the 
development of the chapters in an OER possible within this online graduate program. The project also required a collaborative team effort and members of the team shared their expertise in different aspects that contributed to the project, such as educational technology, participatory pedagogy, open education, digital authoring, editing, copyright and licensing. The team's diverse expertise and commitment to open pedagogy has allowed it to continue to develop OER in subsequent iterations of the program, even absent of grant funding. Further study is needed to examine co-design as a participatory pedagogy for strengthening learner engagement as the development of OER in higher education continues to evolve.

\title{
Author's Contributions
}

Conceptualization: VR, BB, MJ, CH; Data curation: MT, NN, BB, VR; Formal Analysis: MT, NN, BB, MJ, VR; Funding acquisition: BB, VR, MJ; Investigation: BB, VR, MJ; Methodology: $\mathrm{MJ}, \mathrm{CH}$, BB, VR; Project Administration: BB; Resources: $\mathrm{CH}$, NN, MT; Software: $\mathrm{CH}, \mathrm{NN}, \mathrm{MT}$; Writing draft, review, and editing: $\mathrm{BB}, \mathrm{CH}, \mathrm{MJ}, \mathrm{VR}, \mathrm{NN}, \mathrm{MT}$.

\section{Open Researcher and Contributor Identifier (ORCID)}

\author{
Barbara Brown (i) https://orcid.org/0000-0002-6862-4157 \\ Christie Hurrell (iD https://orcid.org/0000-0002-6286-5005 \\ Verena Roberts (iD https://orcid.org/0000-0003-3336-7805 \\ Michele Jacobsen (iD https://orcid.org/0000-0002-0639-7606 \\ Nicole Neutzling \\ Mia Travers-Hayward
}

\section{Acknowledgements}

Acknowledgements: Thank you to all students in the Leading in a Digital Age cohort for their involvement in this project beyond the duration of their enrolment in the program and all the external content experts who provided the students with guidance and feedback for their chapters. Thank you to the Taylor Institute for Teaching and Learning at the University of Calgary for supporting open education projects. Thank you to the two OTESSA peer-reviewers for their suggestions and help with strengthening this article.

\section{Funding}

Grant identification: Scholarship of Teaching and Learning Grant, Taylor Institute for Teaching and Learning, University of Calgary

\section{Ethics Statement}

Ethics approval was obtained for the work described in this article REB19-2050

\section{Conflict of Interest}

The authors do not declare any conflict of interest.

\section{Data Availability Statement}

Data is not available as per ethics agreement for this study. Authors have taken responsibility for ensuring that all steps necessary to protect the privacy of human research subjects have been taken. 


\section{References}

Ashton, H. (Ed.) (2017). Structuring equality: A handbook for student-centered learning and teaching practices. The Graduate Centre Learning Collective.

https://www.hastac.org/collections/structuring-equality-handbook-student-centered-learningand-teaching-practices

Barbera, E., Garcia, I., \& Fuertes-Alpiste, M. (2017). A co-design process microanalysis: Stages and facilitators of an inquiry-based and technology-enhanced learning scenario. International Review of Research in Open and Distributed Learning, 18(6), 104-126.

https://doi.org/10.19173/irrodl.v18i6.2805

Clinton-Lisell, V. (2021). Open pedagogy: A systematic review of empirical findings. Journal of Learning for Development, 8(2), 255-268. https://j14d.org/index.php/ejl4d/article/view/511

Cronin, C. (2017). Openness and praxis: Exploring the use of open educational practices in higher education. International Review of Research in Open and Distance Learning, 18(5). https://doi.org/10.19173/irrodl.v18i5.3096

DeRosa, R., \& Robison, S. (2017). From OER to open pedagogy: Harnessing the power of open. In R. S. Jhangiani \& R. Biswas-Diener (Eds.), The philosophy and practices that are revolutionizing education and science (pp. 115-124). Ubiquity Press.

https://doi.org/10.5334/bbc.i

DeWaard, H., \& Roberts, V. (2021). Revisioning the potential of Freire's principles of assessment: Influences on the art of assessment in open and online learning through blogging. Distance Education, 42(2) 310-326.

https://doi.org/10.1080/01587919.2021.1910494

DiPietro, P. (2013). Transforming education with new media: Participatory pedagogy, interactive learning and Web 2.0. The International Journal of Technology, Knowledge, and Society, 8(5), 1-11. https://doi.org/10.18848/1832-3669/CGP/v08i05/56321

Farrow, R. (2016). A framework for ethics of open education. Open Praxis, 8(2), 93-109. https://openpraxis.org/articles/abstract/10.5944/openpraxis.8.2.291/

Gee, J. P. (2005). Learning by design: Good video games as learning machines. E-Learning, 2(1), 5-16. https://doi.org/10.2304/elea.2005.2.1.5

Jacobsen, M., Brown, B., Roberts, V., Hurrell, C., Neutzling, N., \& Travers-Hayward, M. (2021). Open learning designs and participatory pedagogies for graduate student online publishing [Proceedings]. International Teaching Online Symposium, University of Windsor, Canada.

Jahnke, I., Meinke-Kroll, M., Todd, M., \& Nolte, A. (2020). Exploring artifact-generated learning with digital technologies: Advancing active learning with co-design in higher education across disciplines. Technology, Knowledge and Learning. https://doi.org/10.1007/s10758-020-09473-3

Paskevicius, M., \& Irvine, V. (2019). Open education and learning design: Open pedagogy in praxis. Journal of Interactive Media in Education, 2019(1), 1-10. http://doi.org/10.5334/jime.512 
Roberts,V. (2019). Open Educational Practices (OEP): Design-based Research on Expanded High School Learning Environments, Spaces, and Experiences. (Doctoral dissertation). PRISM Werklund School of Education, University of Calgary, Calgary, Canada.

http://dx.doi.org/10.11575/PRISM/36998

Roschelle, J., Penuel, W. R. \& Schechtman, N. (2006). Codesign of innovations with teachers: Definition and dynamics. Paper presented at the International Conference of the Learning Sciences, Bloomington, IN.

Sanders, E.B.N, \& Stappers, P.J. (2008) Co-creation and the new landscapes of design. CoDesign: International Journal of CoCreation in Design and the Arts, 4(1), 5-18, https://doi.org/10.1080/15710880701875068

Sarmiento-Pelayo, M. (2015). Co-design: A central approach to the inclusion of people with disabilities. Revista De La Facultad De Medicina, 63(3Sup), 149-154.

http://dx.doi.org/10.15446/revfacmed.v63n3sup.49345

Wiley, D., \& Hilton III, J. L. (2018). Defining OER-enabled pedagogy. The International Review of Research in Open and Distributed Learning, 19(4). https://doi.org/10.19173/irrodl.v19i4.3601

8 Open/Technology in Education, Society, and Scholarship Association Conference Proceedings: 2021, Vol. 1(1) 1-8 